\title{
Wastewater Management Techniques: A Review of Advancement on the Appropriate Wastewater Treatment Principles for Sustainability
}

\author{
Donde Oscar Omondi ${ }^{1,2,3,4}$ (Corresponding author) \\ ${ }^{1}$ Key Laboratory of Algal Biology of Chinese Academy of Sciences- Lake Restoration \\ Research Group, Institute of Hydrobiology, Chinese Academy of Sciences \\ Wuhan 430072, People's Republic of China \\ ${ }^{2}$ University of Chinese Academy of Sciences, Beijing 100049 \\ People's Republic of China \\ ${ }^{3}$ Egerton University, Department of Environmental Science, P. O. Box 536-20115 \\ Egerton-Kenya \\ ${ }^{4}$ Kenya Marine and Fisheries Research Institute, Lake Turkana Research Station \\ P. O. Box 205-30500, Lodwar, Kenya \\ E-mail: oscinho@yahoo.co.uk
}

Received: October 11, 2016 Accepted: November 3, 2016

doi:10.5296/emsd.v6i1.10137ＵRL: https://doi.org/10.5296/emsd.v6i1.10137

\begin{abstract}
Water is an essential resource that is required to sustain life. Its availability has to be adequate, safe and easily accessible. Current trends in climate change and rise in human population has compromised water adequacy, availability and safety. Wastewater managers around the world have the responsibility to ensure that the effluent that is eventually released into the environment does not degrade the quality of the recipient water bodies. Attaining sustainability in wastewater management is top in the of Sustainable Development Goals' Agenda. All in all, the realization of a more sustainable wastewater management will require a highly holistic and balanced approach in evaluating a particular management strategy's overall sustainability. Promoting the use of safe, affordable and adequately available wastewater treatment techniques is a step towards wastewater management for sustainability. This review paper therefore discusses some of the currently known and emerging wastewater management techniques that are considered essential in attaining
\end{abstract}


sustainability in water resource management.

Keywords: Quality, Improvement, Management, Sustainability, Treatment, Wastewater

\section{Introduction}

Water is an essential resource that is required to sustain life, it has to be availed in an adequate, safe and easily accessible manner. Wastewater managers around the world have the responsibility to ensure that the effluent that is eventually released into the environment does not degrade the quality of the recipient water bodies. (Mendes and Domingues 2015; Venesa et al., 2015). The increasing identification of different kinds of contaminants in wastewater has been one of the key challenges to environmental integrity and sustainability worldwide (Schwarzenbach, 2006). Indeed, increase in human population coupled with climate change phenomena have consequently lead to rise in pressures applied to wastewater handling facilities (Rop et al 2016), and as a consequence, the existing freshwater resources are increasingly becoming polluted and unavailable. In fact, the crucial issues regarding the quality of water is the presence of several environmental contaminants, including endocrine disrupters compounds, pharmaceuticals and personal care products and other pathogenic organisms and dangerous substances, all of which have been identified in most waste water handling facilities. The concern with all these contaminants is the uncertainty surrounding their adverse effects (Venesa et al., 2015). Therefore, wastewater managers should employ an holistic and comprehensive risk assessment techniques and risk management approach in dealing with water pollution issues to ensure the safety and sustainability of all aquatic systems (WHO, 2011 a, b; Harikishore and Lee, 2012).

\section{Sustainability in Wastewater Management}

There are different tools that can be adopted in wastewater sustainability assessment. These assessment tools may be based on energy flow, economic analysis as well as life cycle assessment. Even though most assessment only takes into account one tool at a time, but due to complexity in the nature of pollutants in wastewater, the use of a balanced set of indicators that provides a holistic assessment is required. (Metcalf and Eddy, 2003). However, the choice of a particular set of indicators may vary from community to community based on geography, culture, and population served. Most studies have highlighted several lists of indicators that are required in assessing sustainability of wastewater management and wastewater treatment technologies (Balkema, 1998; Balkema et al., 2002). Most wastewater sustainability studies are comprehensive and have included multi-disciplinary set of indicators. However, majority of them have only focused on evaluating one treatment technology without comparing different treatment technologies and are one dimensional in terms of evaluating sustainability as they only evaluate environmental stressors. Other studies that measure economic and environmental issues associated with wastewater treatment have not fully embraced societal issues. In this regard, they have not holistically captured the overall sustainability that should be inclusive of a balance of economic, environmental and social considerations (Hwang and Hanaki, 2000; Tsagarakis et al., 2002; Dixon et al., 2003). For end to end sustainability in wastewater management, selection of a particular wastewater treatment technology should not be primarily based on technical insight, but should also integrate the human and environmental activities 
that surround it (Muga and Mihelcic, 2007).

Wastewater treatment should not be focused on one contaminant, since there is no "one-size-fits-all". There must be a balance competing factors that in-cooperate adequate disinfection to protect public health, minimizing disinfection by-product (DBP) formation, minimizing greenhouse gas (GHG) footprint and also reducing neighbourhood impacts (Paul and Swaim, 2016). It also requires a well-defined decision process that includes a clear problem definition, transparent and inclusive sustainability assessment methodology as well as clear and measurable criteria to assess sustainability (triple bottom line) (Curl et al., 2010; Paul and Swaim, 2016). A non-sustainable wastewater management strategy may have impacts that will extend beyond its immediate operational vicinity and even into future generations. In this regard, traditional sustainability indicators for wastewater systems that have only emphasized environmental stressors at the neglect of societal should be made to in-cooperate current and intergenerational balanced impacts. Additionally, the design of wastewater management systems that are better integrated into larger community needs could be considered. For instance, the reuse of treated wastewater and management of solid residuals could be better integrated with local agriculture practices which would re-distribute and return nutrients back to the surrounding environment, instead of concentrating nutrient fluxes in one receiving water body. Ideally the use of onsite-treatment systems like septic tanks, constructed wetlands as well as composting latrines all have potential in embracing sustainability as most of them rely on non-energy and chemical intensive processes that return nutrients to the surrounding environment. All in all, the realization of more sustainable wastewater management will require a highly balanced approach in evaluating a particular management strategy's overall sustainability to a more sustainable development (Muga and Mihelcic, 2007; Curl et al., 2010; Paul and Swaim, 2016).

\section{Wastewater Management Principles}

Wastewater treatment and management is the overall process that involves the improvement of the quality of wastewater between points of production and points of discharge (Fig. 1). This process is aimed at improving the physical, biological and chemical properties of wastewater to eliminate both the known and emerging contaminants from the water eventually available for release into the environment (De et al., 2012; Bruce et al., 2015). Biological treatment has gained much ground over other methods since it has become an important and integral part of any wastewater treatment plant that treats wastewater from different sources having soluble organic impurities or a mix of different wastewater sources (Shrestha, 2005; Gonzales et al., 2016). The obvious economic advantage of this new dimension of wastewater treatment over other treatment processes has cemented its place in any integrated wastewater treatment plant. Biological treatment using aerobic activated sludge process has been in practice for well over a century and is undergoing more and more modification and improvements (WHO, 2004). Rise in pressure to meet more stringent discharge standards by different agencies has led to implementation of a variety of advanced biological treatment processes in recent years (Vymazal, 2011). 


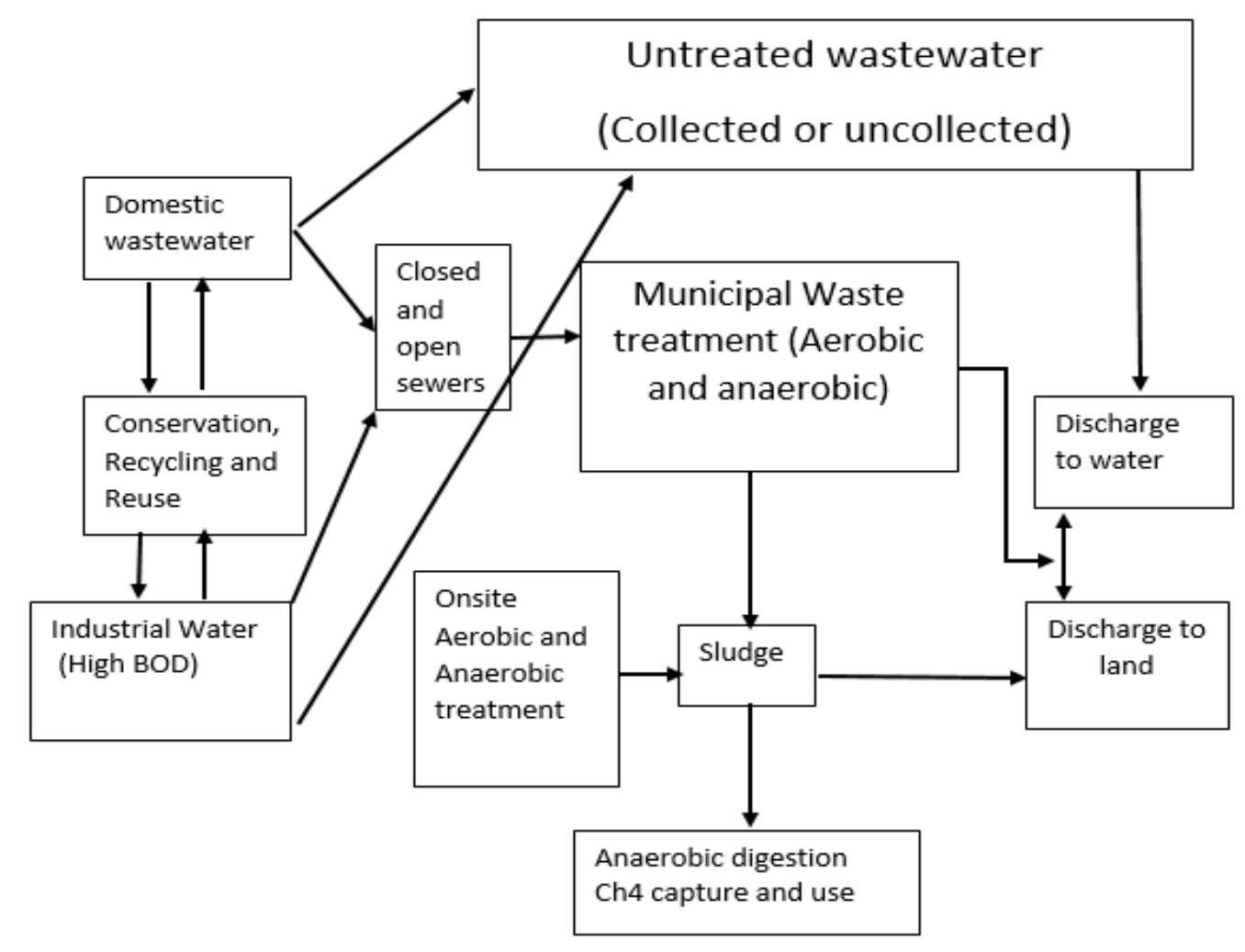

Figure 1. Integrated wastewater management system

The option adapted in wastewater treatment system has to be closely related to the standards and/or expectations set for the effluent quality standards (WHO, 2011; World Water Assessment Programme (WWAP), 2012). Wastewater treatment processes are always designed to achieve improvements in the quality of the wastewater (Shrestha, 2005; Okoh et al., 2010). The various treatment processes can be undertaken to improve the quality of water. This can reduce suspended solids (physical particles that can clog rivers or channels as they settle under gravity), biodegradable organics (e.g. BOD) which can serve as "food" for microorganisms in the receiving body (Al-Mohammed et al., 2013; Ikhajiagbe et al., 2014; Rop et al., 2014). Microorganisms combine this matter with oxygen from the water to yield the energy they need to thrive and multiply; unfortunately, this oxygen is also needed by fish and other organisms in the river (Berehanu et al., 2015). Heavy organic pollution can lead to "dead zones" where no fish can be found; sudden releases of heavy organic loads that can cause sudden fishkills (Cuvin-Aralar et al., 2001; Stephanie et al., 2013). It can also promote Pathogenic bacteria and other disease causing organisms, the situation is most dangerous where the receiving water is used for drinking, or as source of fish (Donde et al., 2014; 2015). High occurrence of nutrients, including nitrates and phosphates can lead to high concentrations of unwanted algae, which can themselves become heavy loads of biodegradable organic pollutants. Treatment processes may also neutralize or remove industrial wastes and toxic chemicals and this form of treatment should ideally take place at the industrial plant itself, before discharge of their effluent in municipal sewers or water courses (USEPA, 2003; Ling-ling et al 2009; Bruce et al., 2015). 


\section{Macrothink}

Wastewater treatment can either be achieved anaerobically or aerobically (Wafler, 2008; Jeon et al., 2014; Sanjeev et al., 2014). Aerobic treatment processes produce more microorganisms and inorganic end-products (principally $\mathrm{CO}_{2}, \mathrm{NH}_{3}$, and $\mathrm{H}_{2} \mathrm{O}$ ) (Okoh et al., 2010; De et al., 2012; Bruce et al., 2015) (Fig. 2). On the other hand, the anaerobic treatment processes do assimilate organic impurities to produce methane and carbon dioxide gas and biomass (Tilley, 2014; Zhu et al., 2014) (Fig 3).

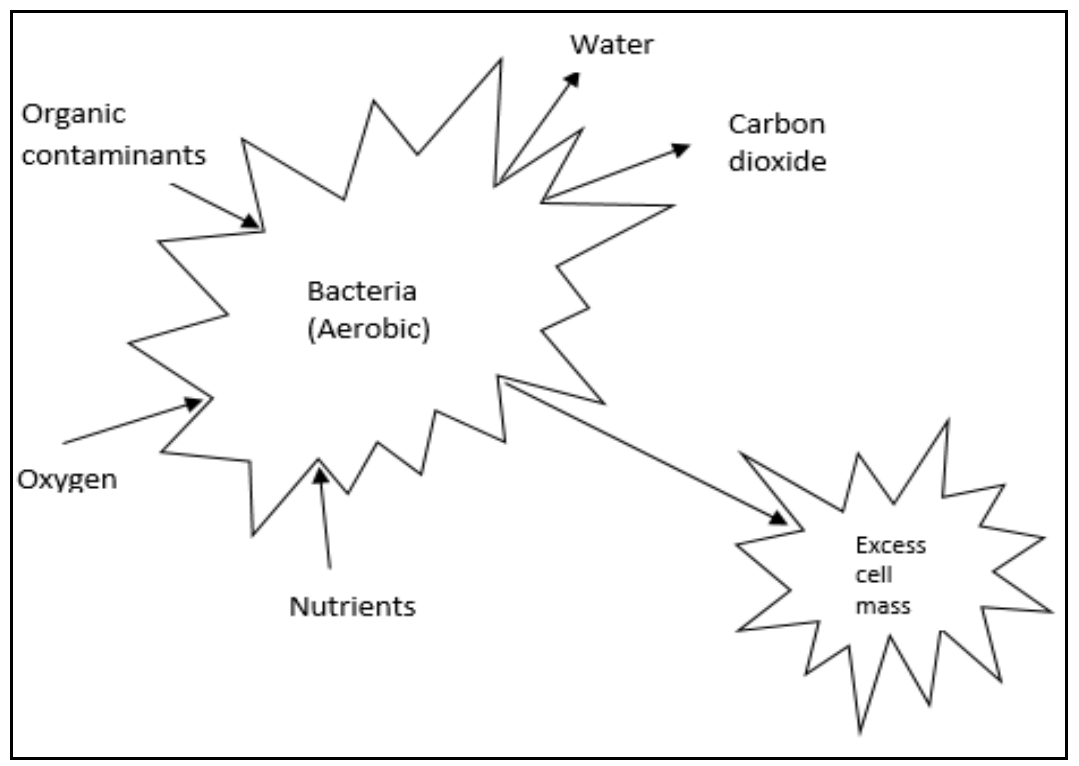

Figure 2. Principle of Aerobic wastewater treatment

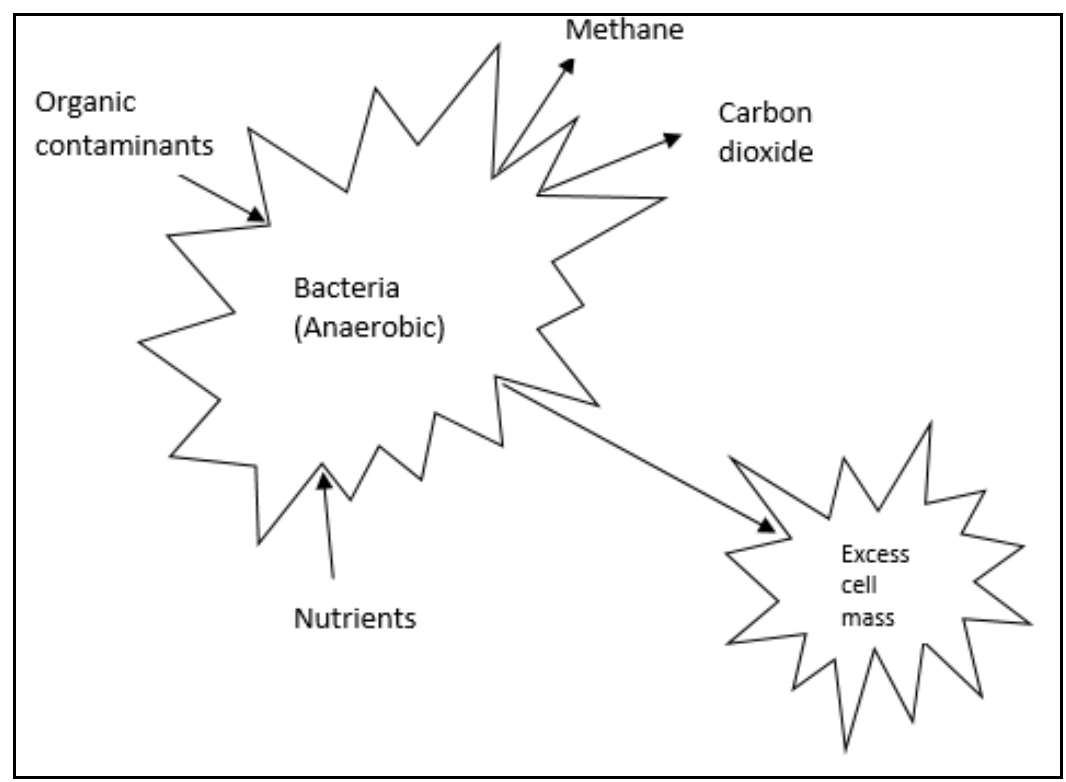

Figure 3. Principle of Anaerobic wastewater treatment

\section{Wastewater Treatment Techniques}

Treatment of wastewater can be undertaken in three stages: primary, secondary, and tertiary (or advanced). Primary or mechanical stage is designed to remove gross, suspended and 
floating solids from raw sewage that is direct from the source. It includes screening to trap solid objects and sedimentation by gravity to remove suspended solids that come from the catchment (Mannie and Bower 2014). Secondary stage is designed to remove the dissolved organic matter that escapes primary treatment. This stage comprises of microbes consuming the organic matter as food, and converting it to carbon dioxide, water, and energy for their own growth and reproduction (Tilley, 2014; Benammar et al., 2015; Dharmender et al., 2016). Generally, high-rate biological processes are normally characterized by relatively small reactor volumes and high concentrations of microorganisms compared with low rate processes (Mang and Li, 2010; Jeon et al., 2014; Sanjeev et al., 2014). Secondary treatment may involve activated sludge, this is a process that involve the dispersed-growth reactor which is an aeration tank or basin containing a suspension of the wastewater and microorganisms, the mixed liquor. The contents of the aeration tank are mixed vigorously by aeration devices which also supply oxygen to the biological suspension (Tilley, 2014; Irene et al., 2016).

Conventional Activated Sludge Process (CASP) System is the most common and oldest bio-treatment process used to treat municipal and industrial wastewater (Madoni 1994; Cordi et al., 2012; Mang and Li, 2010; Arun, 2011; Cordi et al., 2012). The process may also employ trickling filters, which are basins or tower filled with support media such as stones, plastic shapes, or wooden slats where wastewater is applied intermittently, or sometimes continuously, over the media (Wilson et al., 2015). As the waste flows, microorganisms become attached to the media and form a biological layer or fixed film. Organic matter in the wastewater then diffuses into the film, where it is metabolized. Oxygen is normally supplied to the film by the natural flow of air either up or down through the media, depending on the relative temperatures of the wastewater and ambient air. Forced air can also be supplied by blowers but this is rarely necessary. The thickness of the biofilm increases as new organisms grow. Periodically, portions of the film 'slough off the media. The sloughed material is separated from the liquid in a secondary clarifier and discharged to sludge processing. Clarified liquid from the secondary clarifier is the secondary effluent and a portion is often recycled to the biofilter to improve hydraulic distribution of the wastewater over the filter (Wafler, 2008; Wilson et al., 2015). There may also be rotating biological contractors which are fixed-film reactors similar to biofilters in that organisms are attached to support media. These support media are slowly rotating discs that are partially submerged in flowing wastewater in the reactor (Galvaân et al., 2000; Tawfik et al., 2006; Cortez et al., 2008; Manoj et al., 2015).

\section{Advancement in Wastewater Treatment for Environmental Sustainability}

To increase the efficiency of wastewater treatment, an additional stage has always been incorporated. The tertiary wastewater treatment stage can remove more than 99 percent of all the impurities from sewage, producing an effluent of almost drinking-water quality status (Vymazal, 2009; Francisca et al., 2016). An application of a typical tertiary treatment process is the modification of a conventional secondary treatment plant to remove additional nutrients such as phosphorus and nitrogen. The current trend of tertiary treatment is working towards reducing the use of chemicals by promoting natural processes in waste removal. (Vymazal, 
2009; De la Cruz et al., 2013). Effluent from primary clarifiers flows to the biological reactor, which is physically divided into five zones by baffles and weirs (Arun, 2011; De la Cruz et al., 2013). In sequence these zones are; anaerobic fermentation zone (characterized by very low dissolved oxygen levels and the absence of nitrates, anoxic zone (low dissolved oxygen levels but nitrates present), aerobic zone (aerated), secondary anoxic zone and final aeration zone. The function of the first zone is to condition the group of bacteria responsible for phosphorus removal by stressing them under low oxidation-reduction conditions, which results in a release of phosphorus equilibrium in the cells of the bacteria. On subsequent exposure to an adequate supply of oxygen and phosphorus in the aerated zones, these cells rapidly accumulate phosphorus considerably in excess of their normal metabolic requirements. Phosphorus is removed from the system with the waste activated sludge (Pickford, 1987; De la Cruz et al., 2013).

Tertiary wastewater treatment has been modified overtime to include both overland and macrophyte treatment of wastewater (natural wetlands). Overland treatment of wastewater involves overland flow treatment in which effluent is distributed over gently sloping grassland on fairly impermeable soils allows the wastewater to move evenly down the slope to collecting ditches at the bottom edge of the area and water-tolerant grasses are an essential component of the system (USEPA, 1995; De et al., 2012; Bruce et al., 2015; Rafiee et al., 2016). The application rate for wastewaters will depend principally on the type of soil, the quality of wastewater effluent and the physical and biochemical activity in the near-surface environment. Rational design procedures, based on the kinetics of BOD removal, is under modification for overland flow systems (Middlebrooks et al. 1982; Yaman et al., 2006). Under this technology, the cover crop is an important component of the system since it prevents soil erosion, provides nutrient uptake and serves as a fixed-film medium for biological treatment. Crops best suited to overland flow treatment are grasses with a long growing season, high moisture tolerance and extensive root formation. Reed canary grass has a very high nutrient uptake capacity and yields a good quality hay, other suitable grasses may include rye grass and tall fescue (Kadlec et al., 2007). Suspended and colloidal organic materials in the wastewater are removed by sedimentation and filtration through surface grass and organic layers. Removal of total nitrogen and ammonia is inversely related to application rate, slope length and soil temperature. Phosphorus and trace elements removal is by sorption on soil clay colloids and precipitation as insoluble complexes of calcium, iron and aluminium (Suzanne et al 2015). Overland flow systems also remove pathogens from sewage effluent at levels comparable with conventional secondary treatment systems, without chlorination. A monitoring programme should always be incorporated into the design of overland flow projects both for wastewater and effluent quality and for application rates (Suzanne et al 2015; Olilo et al., 2016).

\section{Macrophyte Treatment of Wastewater (Wetlands)}

Maturation ponds which incorporate floating, submerged or emergent aquatic plant species are termed macrophyte ponds and these have been used in recent years for upgrading effluents from stabilization ponds. Macrophytes take up large amounts of inorganic nutrients (especially $\mathrm{N}$ and $\mathrm{P}$ ) and heavy metals (such as $\mathrm{Cd}, \mathrm{Cu}, \mathrm{Hg}$ and $\mathrm{Zn}$ ) as a consequence of the 
growth requirements and decrease the concentration of algal cells through light shading by the leaf canopy and, possibly, adherence to gelatinous biomass which grows on the roots (Shah et al., 2015). A set up of floating macrophyte systems utilizing water hyacinth and receiving primary sewage effluent in Florida achieved secondary treatment effluent quality with a 6day hydraulic retention time, water depth of $60 \mathrm{~cm}$ and hydraulic loading $1860 \mathrm{~m}^{3} / \mathrm{ha}$. Additionally, similar results had also been observed for artificial wetlands using emergent macrophytes (Kadlec et al., 2007; Jensen and Gujarathi, 2015; Shah et al., 2015).

\section{i. $\quad$ Floating Aquatic Macrophyte Systems}

Floating macrophyte species, with their large root systems, are very efficient at nutrient stripping. Although several genera have been used in pilot schemes, including Salvinia, Spirodella, Lemna and Eichhornia, Eichhornia crassipes (water hyacinth) has been studied in much greater detail (Sounders et al., 2007; Vymaza, 2011; Outa et al., 2014; Peixotoet al., 2016. In tropical regions, water hyacinth doubles in mass about every 6 days and a macrophyte pond can produce more than $250 \mathrm{~kg} / \mathrm{ha}$ (dry weight). Nitrogen and phosphorus reductions of up to $80 \%$ and 50\% have been achieved. In Tamil Nadu, India, studies have indicated that the Ceratophyllum demersum, a submerged macrophyte, is very efficient at removing ammonia (97\%) and phosphorus (96\%) from raw sewage and also removes $95 \%$ of the $\mathrm{BOD}_{5}$. It has a lower growth rate than Eichornia crassipes, which allows less frequent harvesting (Outa et al., 2014; Peixoto et al., 2016).

In such macrophyte pond systems, apart from any physical removal processes which might occur (especially sedimentation) the aquatic vascular plants serve as living substrates for microbial activity, which removes BOD and nitrogen, and achieves reductions in phosphorus, heavy metals and some organics through plant uptake (Sounders et al., 2012). The basic function of the macrophytes in the latter mechanism is to assimilate, concentrate and store contaminants on a short-term basis. Subsequent harvest of the plant biomass results in permanent removal of stored containments from the pond treatment system. Potential growth rates of selected aquatic macrophytes cultured in nutrient water Kadlec. The nutrient assimilation capacity of aquatic macrophytes is directly related to growth rate, standing crop and tissue composition. The potential rate of pollutant storage by an aquatic plant is limited by the growth rate and standing crop of biomass per unit area. Water hyacinth, for example, was found to reach a higher standing crop level (Sounders et al., 2012; Outa et al., 2014; Shah et al., 2015).

Fly and mosquito breeding is a problem in floating macrophyte ponds but this can be partially alleviated by introducing larvae-eating aquatic biota such as fish species into the ponds (Berg et al., 2010). A study revealed that pathogen die-off is poor in macrophyte ponds as a result of light shading and the lower dissolved oxygen and $\mathrm{pH}$ as compared to algal maturation ponds (Stephan et al., 2015). In their favor, macrophyte ponds can serve a useful purpose in stripping pond effluents of nutrients and algae and at the same time produce a harvestable biomass. Floating macrophytes are fairly easily collected by floating harvesters. The harvested plants can serve as animal feed, green manure in agriculture, can be composted aerobically to produce a fertilizer and soil conditioner, or can be converted into biogas in an anaerobic digester, in 
which case the residual sludge can then be applied as a fertilizer and soil conditioner (UN Economic and Social Commission for Asia and the Pacific 1981; Jensen and gujarathi, 2015).

\section{ii. Emergent Macrophyte Treatment Systems}

In recent years, natural and artificial wetlands and marshes have been adopted in the treatment of raw sewage and partially-treated effluents (Jensen and Gujarathi, 2015; Shah et al., 2015). Natural wetlands are usually unmanaged, whereas artificial systems are specially designed to maximize performance by providing the optimum conditions for emergent macrophyte growth (Vymaza, 2011). The key features of such macrophyte bed treatment systems are;

a) Rhizomes of the macrophytes grow vertically and horizontally in the soil or gravel bed, opening up 'hydraulic pathways' (Borkar and Mahatme 2015).

b) Wastewater BOD and nitrogen are removed by bacterial activity; aerobic treatment takes place in the rhizosphere, with anoxic and anaerobic treatment taking place in the surrounding soil (Ana et al., 2014).

c) Oxygen passes from the atmosphere to the rhizosphere via the leaves and stems of the reeds through the hollow rhizomes and out through the roots (Ana et al., 2014; Glaister et al., 2014.

d) Suspended solids in the sewage are aerobically composted in the above-ground layer of vegetation formed from dead leaves and stems (Ana et al., 2014; Payne et al., 2014).

e) Nutrients and heavy metals are removed by plant uptake (Glaister et al., 2014; Payne et al 2014).

f) The growth rate and pollutant assimilative capacity of emergent macrophytes are limited by the culture system, wastewater loading rate, plant density, climate and management factors (Borkar and Mahatme 2015).

g) Pathogenic microorganisms are reduced through sieving and deposition that increases their die-off chances (Jenny et al., 2013; Chandrasena et al., 2014)

Studies have shown high tissue $\mathrm{N}$ concentrations in plants cultured in nutrient enriched (wastewater) systems (Borkar et al., 2015). However, because emergent macrophytes have more supportive tissue than floating macrophytes, they might have greater potential for storing the nutrients over a longer period. Consequently, frequent harvesting might not be so necessary to achieve maximum nutrient removal although harvesting above-ground biomass once a year may improve overall nutrient removal efficiency (Shrestha, 2005; Payne et al., 2014).

\section{iii. Constructed wetlands}

Constructed wetland is a designed and man-made complex of saturated substrates, emergent and sub-mergent vegetation, animal life, and water that simulates natural wetlands for water purification (Figure 4), they are increasingly being used worldwide to reduce pollutant loads from different sources. (Wong et al. 1999; Ana et al., 2014; Namratha et al., 2016). Wetlands provide a number of functions and values with the constructed ones providing water quality improvement which is very significant in the control of water borne diseases (Davison et al, 


\section{Macrothink}

2005; Borkar et al., 2015). The technology of wastewater treatment by means of constructed wetlands was started in Germany and involved horizontal flow system which feed in the wastewater at the inlet and flows slowly through the porous medium under the surface of the bed in a more or less horizontal path until it reaches the outlet zone where it is collected before leaving via level control arrangement at the outlet (Vymazal, 2009; Ana et al., 2014; Namratha et al., 2016). During this passage, the wastewater will come into contact with a network of aerobic, anoxic and anaerobic zones. The aerobic zones occur around roots and rhizomes that leak oxygen into the substrate. Major design parameters, removal mechanisms and treatment performance have been reviewed by Vymazal and Kropfelova (2008) or Kadlec and Wallace (2008). Various types of constructed wetlands may be combined in order to achieve higher treatment effect. These systems are called "hybrid constructed wetlands" (Vymazal, 2005; Haghshenas et al., 2016). For example, Horizontal Flow constructed wetlands suffer from the lack of oxygen in filtration beds and, therefore, nitrification is very low. In order to enhance ammonia removal, Horizontal Flow Constructed Wetlands are commonly combined with Vertical Flow constructed wetlands in a staged manner. Vertical Flow systems have a much greater oxygen transport capacity and, therefore, provide much better conditions for nitrification. However, very limited or no denitrification occurs in Vertical Flow systems. Therefore, the optimum combination of various types of constructed wetlands always depends on the target pollutants (Vymazal, 2009; Weerakoon et al., 2016).

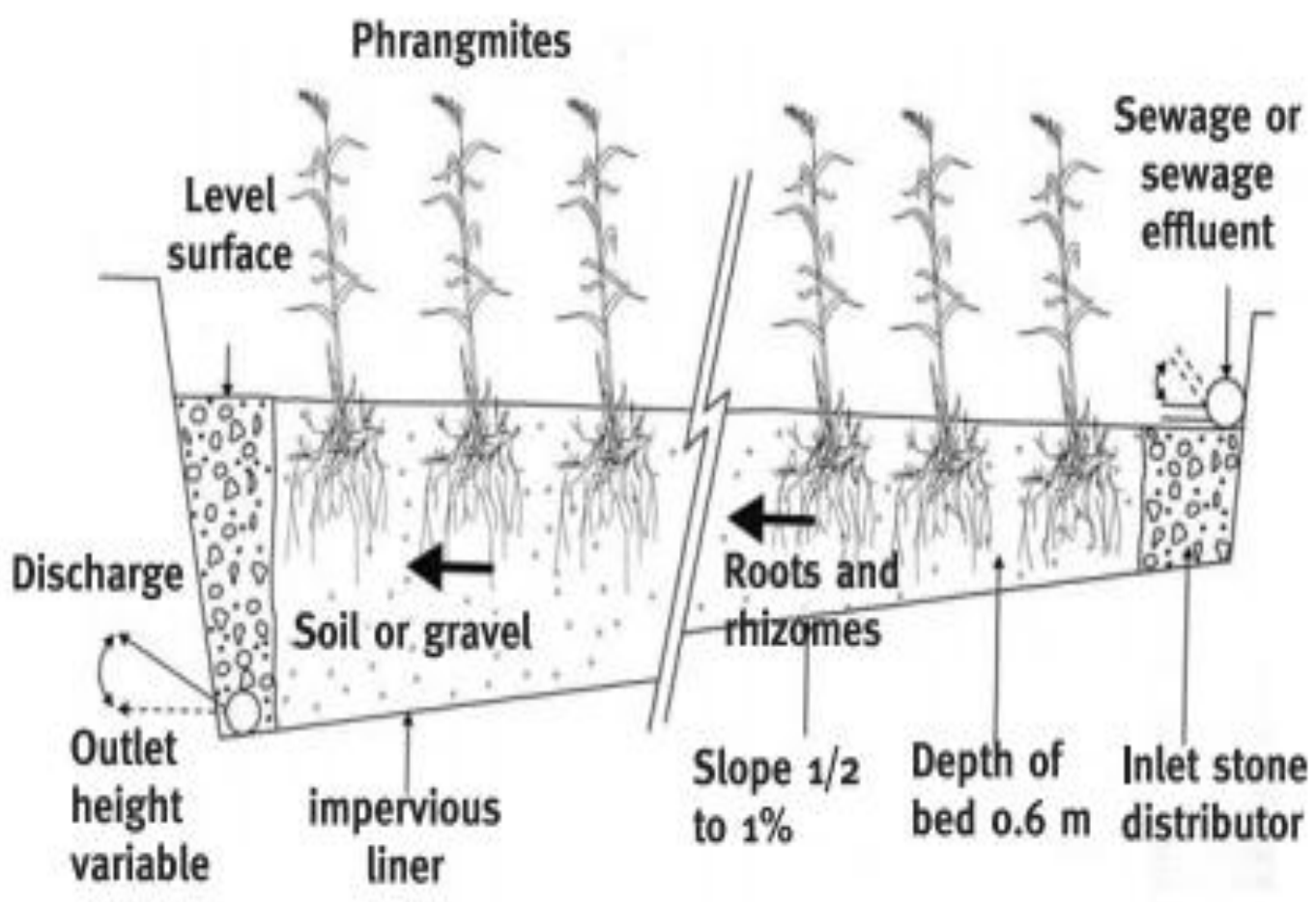

Figure 4. Design of wastewater treatment constructed wetland 


\section{MInstitute Macrink $_{\text {Inth }}$}

iv. Nutrient film technique

The nutrient film technique (NFT) is a modification of the hydroponic plant growth system in which plants are grown directly on an impermeable surface to which a thin film of wastewater is continuously applied (Figure 5), the root production on the impermeable surface is high and the large surface area traps and accumulates matter (Leonard and Leonard, 2006; Castillo et al., 2016). Plant top-growth provides nutrient uptake, shade for protection against algal growth and water removal in the form of transpiration, while the large mass of self-generating root systems and accumulated material serve as living filters (Danaher et al., 2013; Castillo et al., 2016). The system provides roughing or preliminary treatment by plant species with large root systems capable of surviving and growing in a grossly polluted condition. Large sludge accumulations, anaerobic conditions and trace metal precipitation and entrapment characterize this mechanism and a large portion of wastewater BOD and suspended solids would thereby be removed. In addition, nutrient conversion and recovery occurs due to high biomass production and wastewater polishing is attained during nutrient-limited plant production (Leonard and Leonard, 2006; Danaher et al., 2013; Castillo et al., 2016).

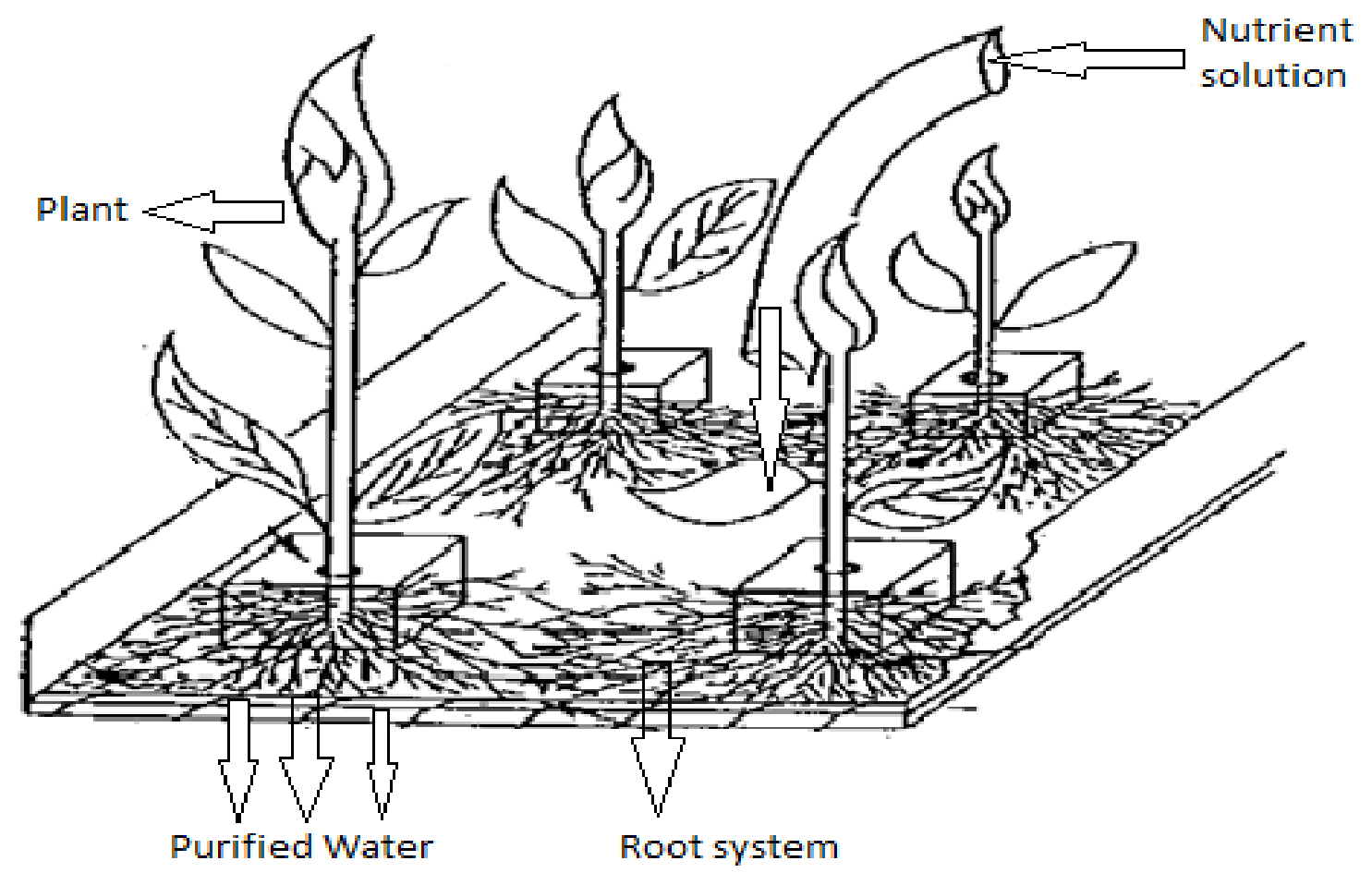

Figure 5. Nutrient film technique variation of integrated wastewater treatment-hydroponic plant production systems

\section{Conclusion}

To achieve sustainability in wastewater management, new concepts need to be developed in view of the fact that the previously known biological wastewater treatment systems are 
sometimes not suitable to holistically solve all the problems associated with known and emerging pollutants. Simple, more cost-effective and sustainability compliant treatment technologies should be preferred as a first step. New wastewater treatment concepts should meet the requirements of adapted wastewater treatment solutions. Biological wastewater treatment step should be added to the mechanical treatment system and hybridized pathways be incorporated to increase the purification efficiencies (Philip et al., 2010). As a way forward, due to continued rise in human population that also results to increase in the amount of waste being generated, therefore, the above discussed technologies still need further improvement and modification to ensure that the quality of water is protected and that current and future human health is not compromised.

\section{Acknowledgement}

The following institutions are much appreciated for their support and opportunities that enhanced the production of this review paper; Key Laboratory of Algal Biology of Chinese Academy of Sciences, Institute of Hydrobiology, Chinese Academy of Sciences, Wuhan 430072, People's Republic of China, University of Chinese Academy of Sciences, Beijing 100049, People's Republic of China, Egerton University, Department of Environmental Science, P. O. Box 536-20115, Egerton-Kenya, and Kenya Marine and Fisheries Research Institute, Lake Turkana Research Station, P. O. Box 205-30500, Lodwar, Kenya

\section{References}

Al-Mohammed, F. M., \& Mutasher, A. A. (2013). Application of water quality index for evaluation of groundwater quality for drinking purpose in Dibdiba aquifer, Kerbala city, Iraq. J. Babylon Univ. Eng. Sci. 5(21), 1660-1660.

Ana D., David Mc., Gayani C., Yali L., Belinda H., Emily P., Kefeng Z., Rebekah H., Peter K., Anja R., Ze M., Bonnie G., Tracey P., \& Jason E. (2014). Biofilters and wetlands for stormwater treatment and harvesting. Cooperative Research Centre for Water Sensitive Cities. Monash University.

Arun Mittal (2011). Biological Wastewater Treatment. Water Today 1 August - 2011. 32-44.

Balkema A., Preisig H., Otterpohl R., \& Lambert J. (2002). Indicators for the sustainability assessment of wastewater treatment systems. Urban Water, 4, 153-161.

Balkema, A., (1998). Sustainability criteria for the comparison of wastewater treatment technologies. Paper for the 11th European Junior Scientist Meeting, 12-15 February 1998, Germany.

Benammar L., Menasria T., Ayachi A., \& Benounis M. (2015). Phosphate removal using aerobic bacterial consortium and pure cultures isolated from activated sludge. Process Saf. Environ. Prot. 95, 237-246.

Berehanu, B., Lemma, B., \& Tekle-Giorgis, Y. (2015) Chemical Composition of Industrial Effluents and Their Effect on the Survival of Fish and Eutrophication of Lake Hawassa, Southern Ethiopia. Journal of Environmental Protection, 6, 792-803. 
Berg J. A., Felton M. J, Gecy J. L., Laderman A. D., Mayhew C. R., Mengler J. L., Meredith W. H., Read N. R., Rey J. R., Roberts C., Sakolsky-Hoopes G. E., Walton W. E., \& Wolfe R. J. (2010). Mosquito Control and Wetlands. Wetland Science and Practice, 27(2), 24-34.

Borkar R. P., \& Mahatme P. S. (2015). Tidal Flow Constructed Wetland: An Overview. International Journal of Engineering and Science, 5(10), 31-34.

Bruce Petrie, Ruth Barden and Barbara Kasprzyk-Hordern (2015). A review on emerging contaminants in wastewaters and the environment: Current knowledge, understudied areas and recommendations for future monitoring. Water Research, 72, 3-7.

Castillo C. D., Zavala L. I., Ruiz V. J., Radilla G. A., Nieto N. J., Romero B. C., \& González-H. C. (2016). Implementation of an experimental nutrient film technique-type aquaponic system. Aquaculture International, 4(2), 637-646.

Chandrasena G. I., Pham T., Payne E. G., Deletic A., \& McCarthy D. T. (2014). E. coli removal in laboratory scale stormwater biofilters: Influence of vegetation and submerged zone. Journal of Hydrology, 519, Part A, 814-822.

Cordi, L, Assalin M. R., Ponezi A. N., \& Durán, N. (2012). Identification of microbiota for activated sludge acclimated by paper mill effluent Kraft E1 Bioremediation. J Bioremed Biodeg, 3, 169.

Cortez S., Teixeira P., Oliveira R., \& Mota M. (2008), Rotating Biological Contactors: A Review On Main Factors Affecting Performance, Rev Environ Sci Biotechnol, 155-172.

Curl, J. M., Ridens, M. P., Swaim, P. D., \& Bellamy, W. D. (2010). Water versus energy and greenhouse gases: The numbers that tell the tale. Proceedings of the Annual Conference and Exposition. Denver, USA: American Water Works Association.

Cuvin-Aralar M. L., Santiago A. E., Gonzalal A. c., Santiago C. B., Romana-Eguia M. R., Baldia S. F., \& Palisoc Jr. F. (2001). Incidence and causes of mass fish kill in a shallow tropical eutrophic lake (Laguna de Bay, Phillippines). In $9^{\text {th }}$ International conference on conservation and management of lakes. Conference proceedings (pp. 233-236). Shiga, Japan: Prefectural Government.

Danaher J. J., Shultz R. C., Rakocy J. E., \& Bailey D. S. (2013) Alternative solids removal for warm water recirculating raft aquaponic systems. J World Aquac Soc, 44(3), 374-383.

Davison, L., Headley, T., \& Pratt, K., (2005). Aspects of design, structure, performance and operation of reed beds-eight years' experience in northeastern New South Wales, Australia. Water Science and Technology, 51, 129-138.

De Godos, I., Munoz, R., \& Guieysse, B. (2012). Tetracycline removal during wastewater treatment in high-rate algal ponds. J. Hazard. Mater. 229-230, 446e449.

De la Cruz N., Esquius L., Grandjean D., Magnet A., Tungler A., De Alencastro L. F., \& Pulgarín C. (2013). Degradation of emergent contaminants by UV, UV/H2O2 and neutral 
photo-Fenton at pilot scale in a domestic wastewater treatment plant. Water Res, 47(15), 5836-5845.

Dharmender Y., Vikas P., \& Pramod K. (2016). Enhanced biological phosphorus removal in aerated stirred tank reactor using aerobic bacterial consortium. Journal of water process and engineering, 13, 61-69.

Dixon A., Simon M and Burkitt T. (2003). Assessing the environmental impact of two options for small-scale wastewater treatment: comparing a reedbed and an aerated biological filter using a life cycle approach. Ecological Engineering, 20, 297-308.

Donde, O. O., Muia A. W., Shivoga W. A., Wanga L. A., Charles G. T., \& Irena F. C. (2015). Faecal pollution and solar disinfection of community water sources within Lake Naivasha Basin, Kenya. Journal of Water, Sanitation and hygiene for Development. http://doi.org/10.2166/washdev.2015.150

Donde, O. O., Ojwang O. W., Muia A. W and Wanga L. A. (2014). Bacterial abundance on the skin, gills and intestines of Cyprinus carpio in Lake Naivasha, Kenya: Implications for public health and fish quality. Lakes and Reservoirs: Research and management. http://doi.org/10.1111//re.12050

Francisca, C. M., Soler, J., Alpendurada, M. F., Rui, A. R., Enric, B., \& Vitor, J. P. (2016). Tertiary treatment of a municipal wastewater toward pharmaceuticals removal by chemical and electrochemical advanced oxidation processes. Water research, 105, 251-263.

Galvaân, P. Urbina, F. De Castro (2000). Characterization of Filamentous Microorganisms in Rotating Biological Contactor Biofilms of Wastewater Treatment Plants, Bioprocess Engineering Springer-Verlag, 257-260.

Glaister B. J., Fletcher T. D., Cook, P. L. M., \& Hatt, B. E. (2014). Co-optimisation of Phosphorus and Nitrogen Removal in Stormwater Biofilters: The Role of Filter Media, Vegetation and Saturated Zone. Water Science \& Technology, 69(9), 1961-1969.

Gonzalez, Gil, L, M. Papa, D. Feretti, E. Ceretti, G. Mazzoleni, N. Steimberg, R. Pedrazzani, G. Bertanza, J.M. Lema and M. Carballa. (2016). Is anaerobic digestion effective for the removal of organic micropollutants and biological activities from sewage sludge. Water Research, 102, 211-220.

Haghshenas, A. A., Heidarpour M., \& Tarkesh E. S. (2016) Evaluation of Horizontal-Vertical Subsurface Hybrid Constructed Wetlands for Tertiary Treatment of Conventional Treatment Facilities Effluents in Developing Countries. Water Air Soil Pollut, 227(28), $1-18$.

Harikishore, K. R. D., \& Lee S. M. (2012). Water Pollution and Treatment Technologies. Environ Anal Toxicol, 2(5), 1000-1003.

Hwang, Y., \& Hanaki K. (2000). The generation of $\mathrm{CO}_{2} \mathrm{CO} 2$ in sewage sludge treatment systems: life cycle assessment, Water Science and Technology, 41(8), 107-113. 
Ikhajiagbe, B., Kekere O., Omoregbee O.and Omokha, F. I. (2014). Microbial and physiochemical quality of effluent water from a brewery in Benin city, Midwestern Nigeria. J. Sci. Res. Rep, 3(3), 514-531.

Irene, Mozo, Nicolas Lesage, Mathieu Sperandio \& Yolain Besierre (2016). Impact of sonication on activated sludge properties and consequences on PAH partitioning. Canadian Journal of Chemical Engineering, 94, 244-252.

James Outa, Nzula Kitaka \& Julius Kipkemboi. (2014). Seasonal changes in water quality and biomass of water hyacinth in Lake Naivasha, Kenya. International Journal of Current research, 6(11), 9915-9925

Jenny, A. G., Diego P., \& Janneth A. C. (2013). Effects of plants and the combination of wetland treatment types systems in pathogen removal in tropical climate condition. Ecological Engineering, 58, 57-62.

Jensen, C. D., \& Gujarathi, N. P. (2015), Characterization of a macrophyte microcosm as a surface water treatment system for antibiotics. Environ. Prog. Sustainable Energy, 34, 1605-1612.

Jeon, B., Nam, S., \& Kim, Y. (2014). Treatment of Pharmaceutical Wastewaters by Hydrogen Peroxide and Zerovalent Iron. Environmental Engineering Research

Kadlec, R. H., Wallace, S. D. (2008). Treatment Wetlands, 2nd ed. CRC Press, Boca Raton, FL.Hammer,D. A. (1989). Constructed wetlands for wastewater treatment: municipal, industrial and agricultural. Lewis Publishers, Inc., Chelsea, MI.

Lennard, W. A., \& Leonard, B. V. (2006). A Comparison of Three Different Hydroponic Sub-systems (gravel bed, floating and nutrient film technique) in an Aquaponic Test System. Aquacult Int, 14(6), 539-550.

Ling-ling, Wang, Zhen-zhen Yu, Hui-chao Dai and Qing-hua Cai (2009). Eutrophication model for river-type reservoir tributaries and its applications Eutrophication model for river-type reservoir tributaries and its applications. Water Science and engineering, 2(1), $16-24$.

Madoni, P. (1994). Microfauna Biomass in Activated Sludge and Biofilm. Water Sci Technol 29, 63-66.

Mang H. P., \& Li, Z. (2010). Technology review of biogas sanitation. Eschborn: Deutsche Gesellschaft für Internationale Zusammenarbeit (GIZ) GmbH.

Mannie, M. N., \& Bower A. (2014). Challenges in Determining the Correct Waste Disposal Solutions for Local Municipalities - A South African Overview. Proceedings of the 20th WasteCon Conference 6-10 October 2014. Somerset West, Cape Town.

Manoj, R. T., Sonali B. P., \& Jyoti R. M. (2015). Review Paper on Study of Rotating Biological Contactor for Wastewater Treatment Process. International Journal of Current Engineering and Technology, 5(3), 1539-1541. 
Mendes, D. S., \& Domingues S. (2015). On the track for an efficient detection of Escherichia coli in water: A review on PCR-based methods. Ecotoxicology and Environmental Safety, $113,400-411$.

Metcalf and Eddy, (2003). Wastewater Engineering: Treatment and Reuse McGraw-Hill, Boston.

Muga, E. H., \& Mihelcik, R. J. (2007). Sustainability of wastewater treatment technologies. Journal of Environmental Management, 88(3), 437-447.

Namratha, N., Harshini, P., Hamsalekha, S., Sindhu, M. S., \& Udayashankara, T. H. (2016). A Review on Removal of Phosphate and Nitrate from Kitchen Wastewater by Constructed Wetlands. International Journal of Modern Trends in Engineering and Research (IJMTER), 03(03), 273-276.

Okoh, A. I., Sibanda, T., Gusha, S.S. (2010). Inadequately treated wastewater as a source of human enteric viruses in the environment. Int. J. Environ. Res. Public Health, 7, 2620-2637.

Olilo, C. O., Onyando, J. O., Moturi, W. N., Muia, A. W., Ombui, P., Shivoga, W. A., \& Roegner A. F. (2016). Effect of vegetated filter strips on transport and deposition rates of Escherichia coli in overland flow in the eastern escarpments of the Mau Forest, Njoro River Watershed, Kenya. Energ. Ecol. Environ, 1(3), 157-182.

Paul, D., \& Swaim, P. E. (2016). Sustainability Principles for Drinking Water and Reuse Treatment. Symposium for Sustainable Infrastructure. Colorado.

Payne, E. G. I., Fletcher, T. D., Cook, P. L. M., Deletic, A., \& Hatt, B. E. (2014). Processes and drivers of nitrogen removal in storm water biofiltration. Critical Reviews in Environmental Science and Technology, 44(7), 796-846.

Peixoto, R. B., Marotta, H., Bastviken, D., \& Enrich Prast (2016). Floating Aquatic Macrophytes Can Substantially Offset Open Water $\mathrm{CO}_{2}$ Emissions from Tropical Floodplain Lake Ecosystems. Ecosystems, 19(4), 724-736.

Philip, J. W. Roberts, Henry J. Salas, Fred M. Reiff, Menahem Libhaber, Alejandro Labbe, James C. Thomson (2010). Marine Wastewater Outfalls and Treatment Systems. IWA Publishing.

Pickford, J. (1987). Developing world water. Grosvenor Press. London UK.

Rafiee, A., Kamyar, Y., Mohammad, H., Saeid, P., Amirhosein, M., Masud, Y., Mehran, K., \& Ramin, N. (2016). Assessment and selection of the best treatment alternative for infectious waste by modified Sustainability Assessment of Technologies methodology. Journal of Environmental Health Science and Engineering, 14(10), 1-14.

Rop, K. R., Muia A. W., Makindi S., \& Donde, O. O. (2014). Changes in the densities of faecal and organic matter contaminants from upstream to downstream along Nyangores river of Mara Catchment, Kenya. Journal of Environmental Science and Water Resources, 
$3(1), 015-25$.

Rop K. Richard, Donde Oscar Omondi, Muia A. Wairimu \& Makindi S. Maingi (2016). Influence of rainfall intensity on faecal contamination in River Nyangores of Mara Basin, Kenya: An eco-health integrity perspective. Asian Jr. of Microbiol. Biotech. Env. Sc, 18(2), 281-289.

Sanjeev Kumar Sinha, Vikas Kumar Sinha, Samir Kr. Pandey, Anup Tiwari (2014). A Study on the Waste Water Treatment Technology for Steel Industry: Recycle and Reuse. American Journal of Engineering Research, 03(04), 309-315.

Saunders M. J., Jones M. B., \& Kansiime F. (2007). Carbon and water cycles in tropical papyrus wetlands. Wetlands Ecology and Management, 15, 489-98.

Saunders MJ, Kansiime F, Jones MB. 2012. Agricultural encroachment: implications for carbon sequestration in tropical African wetlands. Global Change Biology, 18, 1312-21.

Schwarzenbach R.P, Escher BI, Fenner K, Hofstetter TB, Johnson CA, et al. (2006) The challenge of micropollutants in aquatic systems. Science, 313, 1072-1077.

Shah M., Hashmi H. N., Ghumman A. R., \& Zeeshan M. (2015). Performance assessment of aquatic macrophytes for treatment of municipal wastewater. Journal of the South African Institution of civil engineering, 57(3), 18-25. Paper 1011.

Shrestha R. R. (2005) Faecal Sludge Management through Constructed Wetland System in Nepal, Concern \& Quest ENPHO, Environment and Public Health Organisation, Kathmandu Nepal.

Stephan P., Sandra K., Sang-Hyup Lee., Jae-Woo Choi, Seungyun B., Kyu-Sang K., Valeska C. J. (2015). Green Liver Systems ${ }^{\circledR}$ for Water Purification: Using the Phytoremediation Potential of Aquatic Macrophytes for the Removal of different Cyanobacterial Toxins from Water American Journal of Plant Sciences, 6, 1607-1618.

Stephanie L. M., Richard C. T., \& Tamara S. G. (2013). The physical impacts of microplastics on marine organisms: A review. Environmental pollution, 178, 483-492.

Suzanne E. A., Claudia S., Sébastien F. L., George T., \& Pierre L. (2015). Potential Efficiency of Riparian Vegetated Buffer Strips in Intercepting Soluble Compounds in the Presence of Subsurface Preferential Flows. PLoS ONE 10(7), 1-21.

Tawfik, H. Temmink, G. Zeeman \& B. Klapwijk (2006). Sewage Treatment in A Rotating Biological Contactor (RBC) System, National Research Center, Water Pollution Control Dept, 275-289.

Tilley E., Ulrich, L., Luethi, C., Reymond, P., \& Zurbruegg C. (2014). Compedium of Sanitation Systems and Technologies. $2^{\text {nd }}$ Revised Edition. Duebendorf, Switzerland: Swiss Federal Institute of Aquatic Science and Technology (Eawag).

Tsagarakis K. P., Mara D. D., \& Angelakis A. N. (2002). Application of cost criteria for selection of municipal wastewater treatment systems. Water, Air \& Soil Pollution, 142, 
187-210.

United State Environmental Protection Agency (USEPA). (1995). Guidance for risk characterization. Science Policy Council. February 1995.

USEPA (2003). Ultraviolet Disinfection Guidance Manual, draft. Washington DC, Office of Ground water and Drinking water, United States Environmental Protection Agency.

Vanessa de Jesus Gaffney, Cristina M.M. Almeida, Alexandre Rodrigues, Elisabete Ferreira, Maria Jo ao Benoliel and Vitor Vale Cardoso (2015). Occurrence of pharmaceuticals in a water supply system and related human health risk assessment. Water Research, 72, 199-208.

Vymazal, J. (2011). Constructed wetlands for wastewater treatment: five decades of experience. Environmental 695 Science and Technology, 45(1), 65-69.

Vymazal, J. (2009). The use constructed wetlands with horizontal sub-surface flow for various types of wastewater. Journal of Ecological Engineering. Pp 1-17.

Vymazal, J. (2005). Horizontal sub-surface flow and hybrid constructed wetland systems for wastewater treatment. Ecological Engineering, 25, 478-490.

Vymazal, J., \& Kropfelova, L., (2008). Wastewater Treatment in Constructed Wetlands with Horizontal Sub-Surface Flow. Springer, Dordrecht.

Wafler, M. (2008). Training materials on anaerobic wastewater treatment (ecosan expert training course). aarau: seecon gmbh.

Weerakoon, G., Jinadasa, K., Herath, G., Mowjood, M., Dongqing, Z., Soon, K., \& Ng, Wun, J. (2016). Performance of Tropical Vertical Subsurface Flow Constructed Wetlands at Different Hydraulic Loading Rates. CSAWAC, 44(8), 909-1084.

Wilson, S. P., Ouki, S. K., Saroj, D. P., Pearce, P. A., Bancroft, L., \& Germain E. (2015). Adopting Primary Plastic Trickling Filters as a Solution for Enhanced Nitrification. Water Environment Research, 87(1), 80-88.

Wong, T. F. H., Breen, P. F., \& Somes, N. L. G. (1999) Ponds Vs Wetlands \pm Performance Considerations in Stormwater Quality Management. Proceedings of the Comprehensive.

World Health Organization (2004). Guidelines for drinking-water quality, 3rd ed., World Health Organization, Geneva.

World Health Organization (2011). Guidelines for Drinking-Water Quality. 4th ed. WHO; Geneva, Switzerland: 2011. ISBN:978-92-4-154815-1.

World Health Organization, 2011a. Guidelines for Drinking Water Quality. WHO, Geneva, Switzerland.

World Health Organization, 2011b. Pharmaceuticals in Drinking-water. WHO Press, Geneva. World Water Assessment Programme (WWAP) (2012). The United Nations World Water 
Development Report 4: Managing Water under Uncertainty and Risk. UNESCO; Paris, France: 2012.

Yaman C., Martin J. P., \& Korkut E. (2006). Effects of wastewater filtration on geotextile permeability. Geosynthetic International, 13(3), 87-97.

Zhu, G., Li, J., \& Jha, A. K. (2014). Anaerobic treatment of organic waste for methane production under psychrophilic conditions. Int. J. Agric. Biol., 16, 1025-1030.

\section{Copyright Disclaimer}

Copyright for this article is retained by the author(s), with first publication rights granted to the journal.

This is an open-access article distributed under the terms and conditions of the Creative Commons Attribution license (http://creativecommons.org/licenses/by/3.0/). 